\title{
Pemustaka di Perpustakaan Program Pascasarjana ISI Yogyakarta setelah Penerapan Protokol Kesehatan Covid-19
}

\author{
Fl. Agung Hartono ${ }^{1}$ \\ ${ }^{1}$ UPT Perpustakaan Institut Seni Indonesia Yogyakarta \\ Jalan Parangtritis km. 6,5 Yogyakarta \\ HP.: 08156855525; Email: ahaflorentinus@gmail.com
}

\begin{abstract}
Abstrak
Virus Corona atau biasa disebut dengan Covid-19 adalah virus yang menyerang sistem pernapasan manusia.Virus ini masih berhubungan dengan penyebab SARS dan MERS yang sempat merebak beberapa tahun lalu. Sampai saat ini belum diketahui penyebab dari virus corona, tetapi diketahui virus ini disebarkan oleh hewan dan mampu menjangkit dari satu spesies ke spesies lainnya, termasuk manusia. Diketahui virus Corona berasal dari Kota Wuhan di China dan muncul pada Desember 2019. Virus Corona bisa menyebabkan kematian. Bahkan, pasien yang erinfeksi dan sembuh akan mengalami kerusakan permanen pada paru-paru dan antibodi. Kemunculannya ditandai dengan beberapa gejala yang berbeda-beda pada tubuh pasiennya. Namun, secara umum, gejala virus Corona adalah flu, demam, batuk, hingga sesak napas. Gelombang pandemi Covid-19 tak kunjung surut. Meluasnya penularan penyakit yang disebabkan virus korona tipe baru dan bertambahnya kasus infeksi telah mengubah wajah dunia layanan,tanpa terkecuali layanan di Perpustakaan Program Pascasarjana ISI Yogyakarta. Guna meminimalkan risiko terinfeksi protokol kesehatan di lembaga itu diterapkan. Penelitian ini bertujuan untuk mengetahui pengaruh layanan dengan protokol kesehatan itu bagi pemustaka. Dalam penelitian ini, peneliti menggunakan metode penelitian kualitatif karena ingin mendalami suatu fakta, gejala dan peristiwa pengaruh layanan protokol kesehatan terhadap pemustaka. Peneliti menginginkan hasil penelitian berupa rincian data yang lebih kompleks tentang fenomena yang sulit diungkapkan oleh metode kuantitatif dan tidak memerlukan pengolahan data secara statistika. Hasil dari penelitian kualitatif yang dibutuhkan peneliti adalah berupa informasi yang mendalam mengenai pengaruh penerapan protokol kesehatan Covid-19 terhadap perilaku pengguna perpustakaan (pemustaka).
\end{abstract}

Kata kunci: pengaruh; protokol kesehatan; perilaku; pemustaka

\begin{abstract}
Library of ISI Yogyakarta Graduate Program after Implementation of Covid-19 Health Protocol. Corona virus or commonly called Covid-19, is a virus that attacks the human respiratory system. This virus is still related to the cause of SARS and MERS, which had spread a few years ago. Until now, the cause of the corona virus is unknown, but it is known that this virus is spread by animals and can infect from one species to another, including humans. It is known that the Corona virus originated in the city of Wuhan in China and emerged in December 2019. Corona virus can cause death. Infected and cured patients will experience permanent damage to the lungs and antibodies. Its appearance is characterized by several different symptoms in the patient's body. However, in general, the signs of the Corona virus are flu, fever, cough, and shortness of breath. The wave of the Covid-19 pandemic has not subsided. The spread of disease transmission caused by the new type of corona virus and the increase in infection cases have changed the face of the service world, without exception services at the ISI Yogyakarta Postgraduate Program Library. To minimize the risk of being infected, health protocols at the institution are implemented. This study aims to determine the effect of services with the health protocol for users. In this study, the researchers used qualitative research methods to explore a fact, symptom and event of the influence of health protocol services on users.
\end{abstract}


Researchers wish to research results in more complex data details about phenomena that are difficult to express by quantitative methods and do not require statistical data processing. The results of the qualitative research needed by researchers are in the form of in-depth information about the effect of implementing the Covid-19 health protocol on the behaviour of library users (users).

Keywords: effect; health protocol; behaviour; users

\section{A. Pendahuluan}

Pada awal 2020, dunia dihebohkan dengan munculnya virus baru bernama Covid-19. Menurut Badan Kesehatan Dunia (WHO), Covid-19 merupakan keluarga besar Coronavirus, penyebab penyakit pernafasan menular, mulai dari flu biasa hingga kasus yang lebih parah. Sebut saja Middle East Respiratory Syndrome (MERS) dan Severe Acute Respiratory Syndrome (SARS). Kelompok Coronavirus atau virus Corona bersifat zoonosis. Artinya, ditularkan dari hewan ke manusia. Namun, kini penularannya bisa dari manusia ke manusia. Mulanya, virus Covid-19 hanya mewabah di Kota Wuhan, Ibu Kota Provinsi Hubei, China. Kemudian, seiring waktu-tak kurang dari sebulanvirus ini menyebar hampir ke seluruh daratan Negeri Tirai Bambu, bahkan, hingga ke sejumlah negara dunia. Atas kondisi tersebut, maka per tanggal 30 Januari 2020, Badan Kesehatan Dunia (WHO) menjadikan kasus epidemi Covid-19 sebagai Public Health Emergency of International Concern (PHEIC) atau status darurat kesehatan global. Umumnya, seseorang yang terinfeksi virus Covid-19 memiliki gejala klinis seperti demam, batuk, pilek, sakit tenggorokan, letih, dan lesu. Sementara itu, dalam kondisi yang sudah parah, virus Corona dapat menyebabkan pneumonia (penyakit radang paru), sindrom pernafasan akut, gagal ginjal, hingga kematian.

Kasus positif virus Corona atau Covid-19 di Indonesia pertama kali terdeteksi pada Senin 2 Maret 2020. Pertama kali diumumkan oleh Presiden Joko Widodo. Sejak hari itu, jumlah kasus positif Corona semakin bertambah dari hari ke hari. Ada pasien yang meninggal dunia, banyak juga yang dinyatakan negatif dan akhirnya sembuh.
Kasus terkonfirmasi positif Covid-19 di Indonesia menembus 115.056 orang. Terjadi peningkatan sebanyak 1.922 kasus baru Covid-19. Data ini dirilis Satuan Tugas Penanganan Covid-19 pada Selasa 4 Agustus pukul 15.47 Wib. Sementara jumlah pasien sembuh dari Covid-19 juga naik 1.813 orang. Jumlah akumulatif kasus sembuh hingga hari ini menjadi 72.050 orang. Kasus kematian akibat Covid-19 juga bertambah, yakni 86 orang. Total kasus kematian di Indonesia yang disebabkan virus SARS-CoV-2 itu mencapai orang 5.388 orang.

Terkait dengan adanya wabah atau pandemi tersebut. Kementerian Kesehatan (Kemenkes) telah menerbitkan protokol normal baru (new normal) bagi perkantoran dan industri. Hal tersebut diatur dalam Keputusan Menteri Kesehatan Nomor HK.01.07/MENKES/328/2020 tentang Panduan Pencegahan dan Pengendalian Covid-19 di Tempat Kerja Perkantoran dan Industri dalam Mendukung Keberlangsungan Usaha pada Situasi Pandemi.

Dengan keputusan tersebut, tanpa kecuali Kampus Program Pascasarjana ISI Yogyakarta, dalam aktivitas perkuliahan juga harus patuh dengan aturan baru tersebut. Mewajibkan karyawan dan mahasiswa menggunakan masker sejak perjalanan dari/ke rumah, dan selama di tempat kerja, memfasilitasi tempat kerja yang aman dan sehat, higiene dan sanitasi lingkungan kerja, memastikan seluruh area kerja bersih dan higienis dengan melakukan pembersihan secara berkala menggunakan pembersih dan desinfektan yang sesuai setiap 4 jam sekali, terutama pegangan pintu dan tangga, tombol lift, peralatan kantor yang digunakan bersama, area dan fasilitas umum lainya, menjaga kualitas udara tempat kerja dengan mengoptimalkan sirkulasi udara dan sinar 
matahari masuk ruangan kerja, pembersihan filter AC, menyediakan sarana cuci tangan, memasang poster edukasi cara mencuci tangan yang benar, menyediakan handsanitizer dengan konsentrasi alkohol minimal $70 \%$ di tempat-tempat yang diperlukan (seperti pintu masuk, ruang meeting, pintu lift, dll), physical distancing dalam semua aktifitas kerja. Pengaturan jarak antar pekerja minimal 1 meter pada setiap aktifitas kerja, mengkampanyekan Gerakan Masyarakat Hidup Sehat (GERMAS) melalui Pola Hidup Sehat dan Perilaku Hidup Bersih dan Sehat (PHBS) di tempat kerja sebagai berikut: Membudayakan etika batuk (tutup mulut dan hidung dengan lengan atas bagian dalam) dan jika menggunakan tisu untuk menutup batuk dan pilek, buang tisu bekas ke tempat sampah yang tertutup dan cuci tangan dengan sabun dan air mengalir setelahnya, olahraga bersama sebelum kerja dengan tetap menjaga jarak aman, dan anjuran berjemur matahari saat jam istirahat, makan makanan dengan gizi seimbang, hindari penggunaan alat pribadi secara bersama seperti alat sholat, alat makan, dan lain lain.

Pemanfaatan teknologi informasi perpustakaan juga akan memberikan kemudahan bagi pemustaka dalam mengakses informasi di perpustakaan. Dalam penelusuran informasi bahan pustaka atau temu kembali informasi dapat dilakukan dengan menggunakan katalog online atau OPAC (Online Access Public Catalog). OPAC ini dapat memberikan informasi koleksi dan informasi yang ada di perpustakaan karena katalog merupakan wakil dari dokumen di perpustakaan (Agustiawan, 2017: 2).

Semua aturan atau tatanan baru itu mempengaruhi perilaku mahasiswa dalam mengakses fasilitas di kampus terutama di perpustakaan. Aturan baru lewat protokol kesehatan itu menarik untuk diketahui karena berkaitan tentang minat (motivasi) pengunjung perpustakaan atau pemustaka.

Berdasarkan latar belakang di atas maka rumusan masalah penelitian ini adalah kondisi pemustaka di perpustakaan program pasca sarjana ISI Yogyakarta setelah adanya penerapan protokol kesehatan akibat Corona Virus Disease 2019 (Covid-19). Pertanyaan penelitian ini adalah:
Bagaimanakah kondisi pemustaka di perpustakaan tersebut pasca diterapkannya protokol kesehatan sebagai syarat memasuki adat kebiasaan baru atau populer disebut "New Normal".

Berdasarkan permasalahan penelitian tersebut, maka tujuan penelitian ini adalah mengetahui kondisi yang sebenarnya terjadi di perpustakaan tersebut setelah diterapkan protokol kesehatan. Manfaat penelitian ini adalah hasil penelitian ini akan bermanfaat bagi institusi, Program Pascasarjana (PPs) ISI Yogyakarta yaitu masukan dalam pengelolaan layanannya terutama memasuki "normal baru" dengan adanya pandemi Covid-19.

\section{B. Metode Penelitian}

Dalam penelitian ini, peneliti menggunakan metode penelitian kualitatif karena ingin mendalami suatu fakta, gejala dan peristiwa pengaruh layanan protokol kesehatan terhadap pemustaka. Peneliti menginginkan hasil penelitian berupa rincian data yang lebih kompleks tentang fenomena yang sulit diungkapkan oleh metode kuantitatif dan tidak memerlukan pengolahan data secara statistika. Hasil dari penelitian kualitatif yang dibutuhkan peneliti adalah berupa informasi yang mendalam mengenai pengaruh penerapan protokol kesehatan Covid-19 terhadap perilaku pengguna perpustakaan (pemustaka).

Sesuai dengan permasalahan yang diangkat dalam penelitian ini mengenai pengaruh protokol kesehatan terhadap perilakui pemustaka mengunjungi Perpustakaan Program Pascasarjana ISI Yogyakarta maka yang menjadi unit analisis adalah mahasiswa, dosen, karyawan, tamu di lingkungan pascasarajana ISI Yogyakarta yang sering sampai sama sekali tidak pernah ke perpustakaan. Informan penelitian adalah mahasiswa, dosen, karyawan, tamu luar program Pascasarjana yang sering datang ke perpustakaan dan yang jarang berkunjung di perpustakaan.

Sesuai dengan permasalahan yang diangkat dalam penelitian ini mengenai pemustaka di Perpustakaan Program Pascasarjana ISI Yogyakarta maka yang menjadi unit analisis adalah pengguna perpustakaan di program pascasarjana tersebut. Mereka terdiri mahasiswa tiap angkatan baik yang 
menempuh program strata S-2 atapun S-3 pada program studi pengkajian atau penciptaan seni.

Pemilihan informan dalam penelitian ini secara purposive sampling. Teknik pemilihan ini masuk kategori teknik pengambilan sampel nonprobability sampling, teknik ini tidak memberi kesempatan sama bagi setiap unsur untuk dipilih menjadi sampel. Peneliti menentukan sumber data (informan) yang mampu memberikan data untuk menjawab rumusan masalah penelitian ini. Seperti dikatakan Sugiyono (2010) bahwa purposive sampling adalah teknik pengambilan sampel sumber data dengan pertimbangan tertentu. Purposive sampling adalah salahsatu teknik pengambilan sampel yang sering digunakan dalam penelitian. Secara bahasa, kata purposive berarti sengaja. Jadi, purposive sampling berarti teknik pengambilan sampel secara sengaja. Maksudnya peneliti menentukan sendiri sampel yang diambil karena ada pertimbangan tertentu. Sampel diambil tidak secara acak, tetapi ditentukan sendiri oleh peneliti.

Teknik pengumpulan data melalui observasi, dokumentasi dan wawancara mendalam (in depth interview). Peneliti menggunakan daftar pertanyaan yang telah dipersiapkan lebih dahulu yang mencakup garis besar pokok-pokok permasalahan penelitian, dengan menggunakan panduan wawancara (interview guide).

Analisis data dilakukan sejak awal data ditemukan dengan cara menggolongkan dalam pola, mereduksi data untuk memperoleh gambaran yang lebih jealas tentang hasil pengamatan. Kemudian mencari hubungan antara berbagai konsep, mengambil kesimpulan dan verifikasi untuk menjamin validitas. Validasi data dilakukan dengan triangulasi. Kegiatan itu dilakukan secara terus-menerus selama penelitian berlangsung. Gambar 1 menjelaskan tentang pengumpulan data, sehingga menjamin validitas.

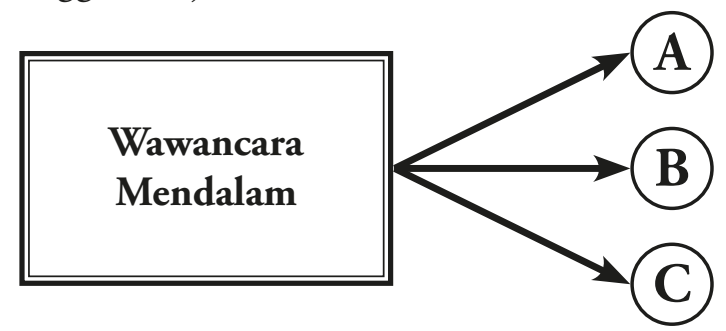

Gambar 1: Triangulasi "sumber" pengumpulan data. (Sumber: Sugiyono, 2010)

\section{Hasil dan Pembahasan}

Motivasi menggunakan atau memanfaatakan fasilitas menurut teori Maslow merupakan kebutuhan paling atas dari hierarki kebutuhan Maslow yaitu aktualisasi diri. Kebutuhan akstualisasi diri meliputi: kebutuhan kognitif: mengetahui, memahami, dan menjelajahi; kebutuhan estetik: keserasian, keteraturan, dan keindahan; kebutuhan aktualisasi diri: mendapatkan kepuasan diri dan menyadari potensinya. Tidak dapat dipungkiri bahwa pandemi covid-19 mempunyai pengaruh yang besar dalam kehidupan seseorang. Dengan diterapkannya protokol kesehatan dalam bentuk jaga jarak, cuci tangan dan memakai masker maka aktivitas manusia, salah satunya aktivatas atau perilaku berkunjung ke kampus dan memanfaatkan fasilitas perpustakaan menjadi aturan hidup baru atau sering disebut era "new normal". Dalam era tatanan normal baru tersebut mempengaruhi dorongan atau motivasi pemustaka dalam berkunjung ke perpustakaan. Ketika pandemi belum menginfeksi masyarakat Indonesia, frekuensi tatap muka berupa pertemuan atau aktivitas fisik masih bebas dilakukan. Namun dengan adanya pandemi semua aktivitas itu dibatasi dalam dengan protokol kesehatan.

Hasil penelitian ini didasarkan pada hasil observasi dan wawancara mendalam terhadap pemustaka di Perpustakaan Program Pascasarjana ISI Yogyakarta. Mereka yang dipilih oleh peneliti dapat memberikan informasi dalam menjawab permasalahan dalam kajian ini. Berdasarkan penelitian yang telah dilakukan dengan observasi dan wawancara dengan informan yaitu pengguna perpustakaan (pemustaka) di Perpustakaan Program Pascasarjana ISI Yogyakarta, maka dapat peneliti jabarkan dalam beberapa poin penting seperti yang tertuang dalam perumusan masalah dalam penelitian ini.

Berdasarkan hasil wawancara dengan beberapa informan dalam penelitian ini, terdapat manfaat positif dengan penerapan protokol kesehatan di perpustakaan Program Pascasarjana ISI Yogyakarta. Seperti dituturkan informan pertama:

"Ketika kesadaran untuk menjaga jarak ditanamkan di kepala publik, secara bersamaan kesadaran kolekstif untuk 
memasuki ruang-ruang virtual digemakan. Maka aneka aktivitas yang lazim digelar dengan pertemuan fisik, seperti bekerja, belajar rapat, seminar, berolahraga, beribadah dipindahkan ke ruang virtual, seperti Zoom, Google Meet, atau WA video call. Saya jadi mengenal dan akrab dengan aplikasi semacam itu.."

Aplikasi pertemuan virtual seperti itu sebenarnya sudah sejak lama dikenal namun jarang digunakan karena mereka merasa nyaman dengan adanya pertemuan fisik, sehingga meski mereka telah mengenal aplikasi pertemuan virtual tersebut mereka sering mengabaikannya. Dengan adanya wabah pandemi covid-19 mahasiswa semakin akrab dengan layar dalam bentuk gawai dan komputer. Seperti diungkapkan informan kelima ini:

"Wabah Covid-19 mendorong jutaan orang memindahkan banyak aktivitas ke ruangruang virtual. Jika ini terus berlangsung, interaksi sosial manusia akan semakin terikat pada layar kecil gawai dan komputer.."

Selain pandemi membawa pengaruh positif pada perubahan perilaku dari kebiasaan bertatap muka ke aplikasi teknologi, juga membawa pengaruh kepada kebiasaan hidup dengan berperilaku hidup sehat. Seperti dituturkan informan kedua:

"Saya jadi mengenal cara hidup yang lebih higienis, lebih sehat, lebih sering mencuci tangan dan menggunakan masker saat berpergian dan berada di tempat umum..."

Informan tiga pun mengungkapkan hal yang sama, sebagai berikut:

"Jaga jarak fisik! Itu salah satu "dokrin" terpopuler saat pandemi Covid-19. Kesadaran itu dibangun bersamaan dengan kesadaran untuk sering-sering mencuci tangan sebagai cara terampuh melawan virus korona baru.."

Dampak positif lain yang ditemui adalah menyangkut motivasi tinggi dari pemustaka. Para pemustaka datang ke perpustakaan di tengah pandemi karena motivasi yang tinggi untuk segera menyelesaikan karya ilmiah atau tugas akhir. Seperti diungkapkan informan ke empat:

"Rasa kuatir sih ada, takut tertular (virus) gitu yah, tapi harus bagaimana lagi saya harus menyelesaikan tugas akhir saya karena sudah melampui batas studi saya. Keseriusaan saya menjadi tekad atau keberanian saya tetap melakukan aktivitas meski harus mematuhi protokol kesehatan.."

Pembatasan sosial dan semakin gencarnya penerapan teknologi sebagai sarana komunikasi secara online, membuat mereka (pemustaka) akrab dengan dunia internet. Kebiasaan mereka berselancar di dunia maya menambah motivasi mereka untuk mencari ilmu pengetahuan, seperti diungkapkan informan lima:

"Internet membuat saya memiliki banyak pilihan dalam pencarian bahan referensi. Kalau biasanya saya mencari buku dalam bentuk fisik di intenet saya bisa mendapatkan buku dalam rupa e-book dan artikel-artikel lain di internet yang mendukung penelitian saya."

Selain itu ada pula responden yang mengungkapkan justru di saat penerapan protokol kesehatan, ada kemudahan dalam birokrasi layanan perpustakaan. Sebelum pandemi pemustaka harus datang untuk mengurus perpanjangan buku, dengan adanya pandemi ini perpustakaan Program Pascasarjana memfasilitasi layanan dalam jaringan (daring) yang bisa memungkinkan pemustaka bertransaksi tanpa harus datang ke kantor. Hal ini dilakukan untuk meminimalisir dampak penularan Covid 19.

"Ada fasilitas layanan lewat WA, kita bisa berkomunikasi dengan petugas melalui aplikasi tersebut termasuk menanyakan informasi tentang buku dan keterlambatan peminjaman..."

Ibarat pisau bermata dua, penerapan protokol kesehatan juga memiliki dampak negatif. Seperti yang dirasakan informan kedua berikut ini:

"Aspek yang cuma terwujud dalam interaksi fisik, seperti kehangatan dan keintiman. Di banyak kampus, mahasiswa sulit berkuliah daring bukan karena tidak terlayani internet tetepai tidak mampu beli kuota. "Setiap kuliah daring paling tidak perlu kuota Rp.10.000-Rp.20.000. Kalau tidak punya kuota, ya tidak bisa kuliah." 
Dampak yang sama juga dirasakan informan tujuh:

"Wabah Covid-19 mendorong jutaan orang memindahkan banyak aktivitas ke ruangruang virtual. Jika ini terus berlangsung, interaksi sosial manusia akan semakin terikat pada layar kecil gawai dan komputer, suasana yang didapat jelas beda jauh kalau ada pertemuan tatap muka, suasana sakral lebih terasa daripada pertemuan virtual sekarang ini.."

Pandemi yang belum juga berakhir membuat beberapa responden merasa cemas, takut, kuatir ketika melakukan aktivitas ke kampus termasuk berkunjung ke perpustakaan.

"Pasti ada dech rasa takut, cemas meski sudah menerapkan protol kesehatan. Apalagi informasi terus membanjir soal covid-19 ke ruang kita keseharian dan kita belum tahu secara benar atau pasti keakuratan informasi tersebut.."

\section{Kesimpulan dan Saran}

Penelitian ini membahas tentang pengaruh penerapan protokol kesehatan terhadap perilaku pemustaka di perpustakaan di Program Pascasarjana (PPS) ISI Yogyakarta. Dalam hubungannya dengan teori, penelitian ini menggunakan pendekatan fenomenologi. Pendekatan ini berusaha untuk memahami makna dari berbagai peristiwa dan interaksi manusia di dalam situsi yang khusus, yang mana situsi yang khusus disini adalah tindakan beberapa pemustaka dalam hal pemanfaaatan layanan perpustakaan setelah diterapkannya protokol kesehatan sebagai upaya mencegah penularan covid-19 secara masif. Dari situasi itu fenomenologi memandang perilaku manusia, apa yang dikatakan dan dilakukan adalah sebagai suatu produk dari bagaimana melakukan tafsir terhadap dunia mereka sendiri. Berdasarkan hasil analisis dan pembahasan di atas, peneliti dapat simpulkan hal-hal sebagai berikut: Terdapat pengaruh atau dampak positif dan dampak negatif akibat penerapan protokol kesehatan tersebut. Dampak positif, pemustaka menjadi terbiasa dengan teknologi informasi dalam hal ini penggunaan internet sebagai media mendapatkan informasi secara daring (dalam jaringan). Namun pada sisi lain juga terdapat dampak negatif, yaitu terganggunya suasana psikologis pemustaka dalam bentuk perasaan cemas, takut dan khawatir terkena corona.

\section{Saran}

Berdasarkan hasil dan kesimpulan penelitian ini, maka peneliti memberikan saran terhadap penentu kebijakan di Program Pascasarjana ISI Yogyakarta dan perpustakaannya sebagai berikut: 1. Pengelola program pascasarjana perlu menambahkan fasilitas penunjang seperti tempat cuci tangan, hand sanitizer, masker dan pembersihan ruangan secara rutin.

2. Semua staf Perpustakaan Program Pascasarjana ISI Yogyakarta wajib menerapkan protokol kesehatan secara ketat.

\section{Kepustakaan}

Agustiawan. 2017. Efektivitas OPAC (Online Public Access Catalog) di UPT Perpustakaan ISI Yogyakarta Berdasarkan Tinjauan Precision. Yogyakarta: Lembaga Penelitian Institut Seni Indonesia Yogyakarta.

Darwati, Yuli, 2014. Pengertian dan Ruang Lingkup Psikologi Sosial, Banten: Untirta.

Tentinsya, Amanda Belina. 2013. Teori Psikologi Sosial, Paper; Makassar, Ilmu Komunikasi, Fakultas Ilmu Sosial dan Ilmu Politik Universitas Hasanuddin.

Walgito, Bimo. 2004. Psikologi Sosial Suatu Penghantar. Yogyakarta: Andi.

Widyastuti, Yeni. 2014. Psikologi Sosial. Yogyakarta, Graha Ilmu.

\section{Webtografi}

Santosa, Meillanny. 2016. Pengaruh Media Sosial terhadap Perilaku Remaja. https://www. researchgate.net/publication/320328023_ Pengaruh Media Sosial terhadap Perilaku Remaja. Diakses, tanggal 28 Agustus2020 pukul 12.45 WIB.

https://www.tribunnews.com/corona/2020/05/26/ 
pengertian-new-normal-dan-protokolpencegahan-penularan-covid-19-di-tempatkerja. diakses tanggal 28 Agustus,pukul 15.00 Wib. Diunduh dari Web tgl 5 Agustus 2020. https://lifestyle.kompas.com/read/2020/ 03/09/141500920/virus-covid-19-masukindonesia-begini-cara-antisipasinya https://www.merdeka.com/peristiwa/data-terkinijumlah-korban-virus-corona-di-indonesia. html. Keputusan Menteri Kesehatan Republik Indonesia Nomor HK.01.07/ Menkes/328/2020 tentang Panduan Pencegahan dan Pengendalian Corona Virus Disease 2019 (Covid-19) di Tempat Kerja. 